\title{
Transport of Urokinase Across the Intestinal Tract of Normal Human Subjects with Stimulation of Synthesis and/or Release of Urokinase-type Proteins
}

\author{
Naotika Toki \\ Department of Dermatology, Hiroshima University School of Medicine, Hiroshima 734, Japan \\ Hiroyuki Sumi \\ Department of Physiology, Miyazaki Medical College, Miyazaki 889-16, Japan \\ Koji Sasaki \\ Zeria Pharmaceutical Co., Ltd., Central Research Laboratories, Saitama 360-01, Japan \\ Irena Boreisha and Kenneth C. Robbins \\ Department of Pathology, Michael Reese Hospital and Medical Center, Chicago, Illinois 60616
}

\begin{abstract}
Oral administration of clinical-type high molecular weight urokinase (HMW-UK) in a single dose of $30,000-60,000$ International Units (IU) in enteric-coated capsules, in a group of normal human subjects, induced a plasma fibrinolytic state suggesting transport of $\mathrm{HMW}$-UK across the intestinal tract. Other groups of human subjects were given a single dose of 120,000 IU daily of pure HMW-UK for $1 \mathrm{~d}$ and $7 \mathrm{~d}$ together with a placebo dose, all of the ingredients except urokinase (UK), daily for $7 \mathrm{~d}$. UK-type proteins were isolated from the plasma of blood samples drawn $6 \mathrm{~h}$ after administration of the final dose, by a sequential two-step affinity chromatography method first with [ $N^{\alpha}$-( $\epsilon$-aminocaproyl)-DL-homoarginine hexylester-Sepharose and second with a specific rabbit antiHMW-UK-IgG-Sepharose. The yield of UK-type proteins from the 7-d group, $0.79 \mathrm{mg} / \mathrm{dl}$, was $\sim$ twofold greater than that obtained from either the placebo or 1-d groups. The specific plasminogen activator activity of the 1-d and 7-d groups were similar, 508 and $537 \mathrm{IU} / \mathrm{mg}$ protein, respectively; negligible plasminogen activator activity could be detected in the placebo group. The kinetics of activation parameters of human Glu-plasminogen of the UK-type protein, isolated from the 1-d group, were similar to those obtained with urinary HMW-UK. The UK-type proteins isolated only from the 7-d group showed, in sodium dodecyl sulfate (SDS)-polyacrylamide gel electrophoresis, a major protein band of molecular weight 53,000 in the same position as HMW-UK. In addition, two other major protein bands of $\sim 140,000$ and $\sim 120,000 \mathrm{~mol}$ wt were found in the 7-d placebo-, and 1-d groups, and also in the 7-d group. The 53,000 mol wt protein, about $50 \%$ of the total protein in the 7-d group, was further purified by preparative SDS-polyacrylamide gel electrophoresis, and found to be a two-chain protein with a specific activity of $1,241 \mathrm{IU} / \mathrm{mg}$ protein. The protein showed common antigenic determinants with urinary HMW-UK. The oral administration of 120,000 IU HMW-UK to human subjects for 7 d stimulated the synthesis of a UK-type protein of $53,000 \mathrm{~mol} \mathrm{wt}$, probably the zymogen, from either the liver or vascular endothelium, which was released into the circulation, and converted into active UK
\end{abstract}

Address correspondence to Dr. Robbins, Michael Reese Hospital. Received for publication 6 March 1984 and in revised form 31 August 1984.

J. Clin. Invest.

(C) The American Society for Clinical Investigation, Inc.

0021-9738/85/04/1212/11 \$1.00

Volume 75, April 1985, 1212-1222 by circulating plasmin. The induction of the fibrinolytic state produced the conversion of native circulating Glu-plasminogen into the degraded Lys-plasminogen form, which was found in large amounts in the plasma of the 7-d group. The new plasma components, e.g., the 53,000-mol wt UK-zymogen and Lysplasminogen, could play an important role in clot resolution of the fibrin-thrombus in thromboembolic diseases. Oral administration of HMW-UK has been shown to be clinically effective in patients with cerebral thrombosis in a multicenter double blind study.

\section{Introduction}

Urokinase (UK) ${ }^{1}$ is currently being used clinically as a thrombolytic agent in patients with various thromboembolic diseases (1). This therapeutic plasminogen activator has always been infused intravenously in human subjects. We have been studying the oral administration of high molecular weight urinary urokinase (HMW-UK) in a dog model and in normal human subjects, and have reported that orally administered HMWUK was absorbed through the intestinal tract in an experimental dog model and in human subjects (2-5), producing a plasma fibrinolytic state. A plasma fibrinolytic state was developed, as defined by an increase in urokinase amidolytic activity with a specific synthetic substrate, a decreased euglobulin lysis time, and an increase in plasmin activity, in a large series of volunteer normal human subjects after oral administration of either 30,000 or 60,000 International Units (IU) of clinicaltype HMW-UK. After oral administration of 120,000 IU of pure HMW-UK for either $1 \mathrm{~d}$ or daily for $7 \mathrm{~d}$, and oral administration of a placebo daily for $7 \mathrm{~d}$, a new 53,000-mol wt urokinase (UK)-type protein was isolated from plasma samples, from blood drawn $6 \mathrm{~h}$ after administration of the capsules. A sequential two-step affinity chromatography method, followed by preparative sodium dodecyl sulfate (SDS)-polyacrylamide electrophoresis, was used to isolate the UK-type protein. The protein was characterized by functional, SDSpolyacrylamide gel electrophoretic, and immunological methods.

1. Abbreviations used in this paper: $\mathrm{ACH}-\mathrm{Sepharose},\left(\mathrm{N}^{\alpha}-[\epsilon\right.$-aminocaproyl]-DL-homoarginine hexylester)-Sepharose; ELT, euglobulin lysis time; FDP, fibrinogen/fibrin split products; Glu-Plg, Glu-plasminogen H-D-Val-Leu-Lys-pNA， H-D-valyl-L-leucyl-L-lysine-p-nitroanilide; HMW-UK, high molecular weight urokinase; IAEF, immunoadsorbent adsorbed-eluted fraction; LMW-UK, low molecular weight urokinase; NPGB, p-nitrophenyl-p'-guanidinobenzoate; pyro-Glu-Gly-Arg-pNA, L-pyroglutamyl-glycyl-L-arginine-p-nitroanilide; UK, urokinase. 


\section{Methods}

Reagents. Benzamidine $\cdot \mathrm{HCl}$ (Aldrich Chem. Co., Milwaukee, WI), Trasylol (Bayer Pharmaceutical Co., Ltd., Federal Republic of Germany), Pyro-Glu-Gly-Arg-pNA (S-2444; Kabi Diagnostica, Sweden) and H-D-Val-Leu-Lys-pNA (S-2251; Kabi Diagnostica), Sepharose 4B (Pharmacia Fine Chemicals, Piscataway, NJ), bovine thrombin, 90\% pure (Mochida Pharmaceutical Co., Japan), bovine plasminogen-rich fibrinogen (Povite Products, Nakarii Chemicals, Japan), Agarose-L (Behringwerke, Federal Republic of Germany), and plasminogen-free bovine fibrin plates (Daiichi Pure Chemical Co., Japan) were purchased. Human Glu-plasminogen used in the kinetic studies and for plasminogen activator assays was prepared by methods previously described (6). [ $N^{\alpha}$-( $\epsilon$-aminocaproyl)-DL-homoarginine hexylester]-Sepharose (ACHSepharose) was prepared by methods previously described (7).

$U K$ preparations. Enteric-coated gelatin capsules were prepared containing either clinical-type human urinary UK powder, with a specific activity of $40,000 \mathrm{IU} / \mathrm{mg}$ protein $(15,000 \mathrm{IU}, 30,000 \mathrm{IU}$, or 60,000 IU per capsule), or pure HMW-UK powder, with a specific activity of $110,000 \mathrm{IU} / \mathrm{mg}$ protein $(30,000 \mathrm{IU}$ per capsule). The intravenous preparations $(30,000 \mathrm{IU})$ were clinical-type human urinary HMW-UK. The pure HMW-UK was prepared by a previously described affinity chromatography method with ACH-Sepharose, from partially purified urinary HMW-UK (7). It had a molecular weight of 53,000, with $92.8 \%$ active sites by p-nitrophenyl-p'-guanidinobenzoate (NPGB) titration (8). It was similar to the highest purity urinary HMW-UK preparation previously used for kinetic studies $(6,9)$, and was used as the HMW-UK standard in these studies. For the immunodiffusion studies, pure urinary LMW-UK, prepared from partially purified urinary LMW-UK by the ACH-Sepharose method, was used. It had a molecular weight of 33,000 , a specific activity of $230,000 \mathrm{IU} / \mathrm{mg}$ protein, and $91.2 \%$ active sites.

The enteric-coated gelatin capsule contained, in addition to the HMW-UK powder, $6 \mathrm{mg}$ sodium chloride (Wako Pure Chemical Industries, Ltd., Japan), $24 \mathrm{mg}$ glycine (Wako Pure Chemical Industries, Ltd.), $3 \mathrm{mg}$ Bacto-Gelatin (Difco Laboratories Inc., Detroit, MI), 10 mg porcine gastric mucin (Yamanouchi Pharmaceutical Co., Japan), $3 \mathrm{mg}$ sucrose fatty acid ester (Ryoto Co., Ltd., Japan), and $247 \mathrm{mg}$ lactose D.M.V. (Zuid-Nederlandse Melkindustrie b.v., Holland). The placebo capsule contained all of the ingredients with the exception of the HMW-UK powder.

Human subjects. 40 healthy normal Japanese individuals (20 men and 20 women), all volunteers, between the ages of 17-63 yr, weighing from 55 to $65 \mathrm{~kg}$, were selected as subjects for the clinical oral administration groups, and 10 healthy normal Japanese individuals (five men and five women), all volunteers, between the ages of 21-52 yr, were subjects for the intravenous administration group. 30 additional healthy normal persons (15 men and 15 women), all volunteers, between the ages of $25-35 \mathrm{yr}$, weighing from 50 to $65 \mathrm{~kg}$, were selected as subjects for pure HMW-UK and placebo oral administration groups used for the isolation of HMW-UK-type proteins. All individuals were found to have normal concentrations of both the blood coagulation system components and the fibrinolytic system components.

Administration of $U K .40$ human subjects (oral groups) were each given one capsule containing three different doses of clinical-type urinary HMW-UK, 15,000 IU, 30,000 IU, and 60,000 IU, at 1-wk intervals. 10 human subjects (intravenous group) were each given 30,000 IU of clinical-type urinary HMW-UK intravenously in a single bolus. After administration of the HMW-UK preparations, all individuals were required to rest during the blood collection period. Blood samples were collected from each individual after the administration of the HMW-UK employing a two-syringe technique, in a $1 / 10$ vol of $3.8 \%$ citrate, at $2,4,6,8,10$, and $24 \mathrm{~h}$ in the oral group, and at 0.5 , $1,2,4$, and $6 \mathrm{~h}$ in the intravenous group. 30 additional human subjects were separated into three groups. 10 human subjects were each given four placebo capsules, without UK, in a single dose, daily for $7 \mathrm{~d}$ (placebo group). 10 human subjects were each given four capsules containing 30,000 IU of pure HMW-UK per capsule in a single dose (1-d group), and 10 human subjects were each given the same four HMW-UK capsules daily, in a single dose, for $7 \mathrm{~d}$ (7-d group). Plasma fibrinolytic parameters were measured in these three groups at $0.5,2$, $4,6,8,10$, and $24 \mathrm{~h}$ after oral administration of the capsules. In the 7-d group, plasma fibrinolytic parameters were measured only on the seventh day. Blood samples were collected from each individual $6 \mathrm{~h}$ after administration of the final dose; in the three groups given pure HMW-UK, the plasmas of each group were pooled and used for the isolation of the HMW-UK-type proteins. Immediately after separation of the plasma samples, $20 \mathrm{KIU}$ of Trasylol per milliliter plasma and $25 \mathrm{mM}$ benzamidine $\cdot \mathrm{HCl} / \mathrm{ml}$ plasma were added.

Determination of fibrinolytic system components in plasma. UKspecific amidolytic activity was determined in the plasma samples and fractions by a modification of the end-point method described by Claeson et al. (10), with pyro-Glu-Gly-Arg-pNA, measuring released p-nitroaniline (pNA). The system contained $700 \mu 1100 \mathrm{mM}$ Tris-HCl buffer, $\mathrm{pH} 8.8,10 \mathrm{KIU}$ Trasylol, $200 \mu \mathrm{l}$ plasma, or fraction, and 100 $\mu \mathrm{l} 3 \mathrm{mM} \mathrm{S}-2444$. After incubation for $10 \mathrm{~min}$ at $37^{\circ} \mathrm{C}, 100 \mu \mathrm{l}$ of $50 \%$ acetic acid was added to stop the reaction; the absorbance was read at $405 \mathrm{~nm}$. This substrate is useful for determining UK activity, since it is 40 -fold more sensitive to UK than to both plasma plasmin and kallikrein, and 10-fold more sensitive to urokinase than to both thrombin and Factor $\mathrm{Xa}$. It can also be used to measure tissue plasminogen activator. Standard curves can be prepared with either pNA or UK (0-40 IU); $1.00 \mathrm{nmol}$ of pNA is equivalent to $1.15 \mathrm{IU}$ UK activity. The data are presented as nanomoles of pNA liberated per milliliter indicating the possibility that non-UK amidolytic activity is included in the measurement. Plasmin (protease) activity in plasma was measured with a plasminogen-free bovine fibrin plate. $20 \mu \mathrm{l}$ of plasma was placed on the plate, which was incubated at $37^{\circ} \mathrm{C}$ for 16 $\mathrm{h}$, and the lysis area, millimeters squared, was calculated. Plasmin (protease) activity is expressed in casein units per deciliter plasma; the casein unit is equivalent to $0.7 \mathrm{IU}$ of plasmin using a standard curve with a reference human plasmin preparation (IRP 77/588) $(0-1 \times$ $10^{-3}$ casein units). This assay with the fibrin substrate will reflect the protease activity of free plasmin only. Human Glu-Plg activator activity of fractions isolated from plasma was determined with H-D-Val-LeuLys-pNA by an end-point method modification of an initial rate method with highly purified human Glu-plasminogen $(6,9)$. The system contained $825 \mu \mathrm{l} 50 \mathrm{mM}$ Tris- $\mathrm{HCl}$ buffer per $100 \mathrm{mM} \mathrm{NaCl}$, pH 7.4, $100 \mu \mathrm{l} 0.1 \%$ gelatin, $5 \mu \mathrm{l}$ Glu-plasminogen (1.5 casein units), $0-10 \mu$ l activator, incubated for $2 \mathrm{~min}$ at $37^{\circ} \mathrm{C}$, followed by $75 \mu \mathrm{l} \mathrm{S}$ 2251 , and incubated for $5 \mathrm{~min}$ at $37^{\circ} \mathrm{C} ; 100 \mu \mathrm{l}$ of $50 \%$ acetic acid was added and the absorbance was read at $405 \mathrm{~nm}$. A UK standard curve was prepared (0-4 IU). Protein concentration of fractions isolated from plasma was determined by absorbance measurements at $280 \mathrm{~nm}$ using a specific absorbance of $\mathrm{E}_{1 \mathrm{~cm}}^{\%}=13.6$, which is the $\mathrm{E}_{\mathrm{cm}}^{\%}$ of HMW-UK.

ELT was determined by the method of Milstone (11) with a clot lysis time recorder (Riko Shoji Co., Japan); the euglobulin fraction was precipitated from $0.5 \mathrm{ml}$ plasma, removed by centrifugation,

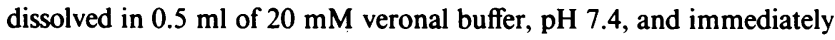
clotted with $0.1 \mathrm{ml}$ bovine thrombin solution $(25 \mathrm{U})$. FDP were measured in serum by a latex agglutination method (12) with a FDPLkit (Teikoku Hormone Mfg. Co., Ltd., Japan). Plasminogen, and two types of antiplasmin, immediate and slow, were determined by an affinity chromatography method with L-lysine-substituted-Sepharose by a method previously described (13). In this method, the plasminogen was removed from the plasma sample by passing it through L-lysineSepharose; the plasminogen was eluted with $100 \mathrm{mM}$ acetic acid, converted to plasmin with streptokinase, and assayed on a casein substrate. The unadsorbed plasma components were assayed for antiplasmin activity by adding excess standard plasmin, incubating at both $0.5 \mathrm{~min}$ and at $30 \mathrm{~min}$, and assaying for residual plasmin on a casein substrate.

Immunological studies. Rabbit antibody to HMW-UK was prepared by immunizing rabbits by both foot pad and intradermal injections with $0.5 \mathrm{mg}(55,000 \mathrm{IU})$ of pure human urinary HMW-UK in Freund's complete adjuvant; a single booster injection of the same amount of protein was given 4 wk later. After another 4-wk period, blood was drawn and incubated at $37^{\circ} \mathrm{C}$ for $3 \mathrm{~h}$, and $4^{\circ} \mathrm{C}$ for $18 \mathrm{~h}$, and the serum was separated by centrifugation at $2,500 \mathrm{~g}$. The specific anti- 
UK IgG antibody was purified by ammonium sulfate fractionation (35\% saturation), DEAE-cellulose column chromatography, and immunoadsorbent column chromatography using HMW-UK-Sepharose 4B according to the method of Wun et al. (14). $1 \mathrm{mg}$ of the IgG antibody fraction neutralized almost completely $80 \mathrm{IU}$ of the parent highly purified urinary HMW-UK when the fibrinolytic activity of the IgG antibody-UK mixture was measured by a standard fibrin plate method according to the method of Day et al. (15). The specific rabbit anti-HMW-UK-IgG-Sepharose was prepared from $20 \mathrm{ml}$ of Sepharose 4B activated by treatment with cyanogen bromide as described by Cuatrecasas (16), and coupled with $20 \mathrm{mg}$ of rabbit anti-HMW-UKIgG (100\% immobilized) in $100 \mathrm{mM}$ borate buffer containing $50 \mathrm{mM}$ $\mathrm{CaCl}_{2}, \mathrm{pH}$ 9.3. The Sepharose slurry was washed first with $200 \mathrm{mM}$ $\mathrm{Na}_{2} \mathrm{CO}_{3}$ containing $500 \mathrm{mM} \mathrm{NaCl}$ followed by $100 \mathrm{mM}$ borate buffer, pH 9.0 , containing $500 \mathrm{mM} \mathrm{NaCl}$.

Double immunodiffusion analysis (Ouchterlony method) (17) was carried out at room temperature for $24 \mathrm{~h}$ in $1.0 \%$ agarose (Behringwerke, Federal Republic of Germany) in a pH 8.6 veronal buffer, ionic strength of 0.05 , containing $0.05 \% \mathrm{NaN}_{3}$.

Plasminogen activation kinetics. Glu-Plg activation kinetics were carried out and calculated in the same manner as was previously described $(6,9)$ where $K_{p l g}$ is the apparent Michaelis constant of activation for the plasminogen substrate, and $\mathrm{k}_{\mathrm{plg}}$ is the catalytic rate constant of activation.

Electrophoretic procedures and zymography. SDS-PAGE was carried out in the Ortec acrylamide gel system by methods previously described (18). Gel slabs $(6 \%)$ were prepared in $0.1 \mathrm{M}$ phosphate, $0.1 \%$ SDS, $0.002 \mathrm{M}$ EDTA buffer, $\mathrm{pH} 7.0$, and electrophoresis was carried out at $320 \mathrm{~V}$ and $120 \mathrm{~mA}$ for $180 \mathrm{~min}$. Samples for analysis were dissolved in $8 \mathrm{M}$ urea, $0.1 \%$ SDS at a concentration of $1-3.5 \mathrm{mg}$ of protein $/ \mathrm{ml}$ and $10 \mu \mathrm{l}$ was placed in each slot. The gel slabs were stained with Coomassie Brilliant Blue R250 for $30 \mathrm{~min}$ at $65^{\circ} \mathrm{C}$ and destained. Gels were scanned, after drying, with a Beckman Model 110 microzone scanner, both to identify and to quantitate each of the components of samples. Plasminogen activator activity of the protein bands separated on the gel of SDS-PAGE was determined by the zymographic technique of Tissot et al. (19); after SDS-PAGE, the gel was washed for $30 \mathrm{~min}$ in $2.5 \%$ Triton X-100 to remove SDS, placed on plasminogen-rich fibrin-agar plate and incubated at $37^{\circ} \mathrm{C}$ for $18 \mathrm{~h}$. The plasminogenrich fibrin-agar plate was prepared as follows: $10 \mathrm{ml}$ of fibrinogen $(0.8 \%)$ in $100 \mathrm{mM}$ phosphate buffer, $\mathrm{pH} 7.4$, was mixed on 13.5 $\times 9.5-\mathrm{cm}$ plastic plates with $2.5 \mathrm{ml}$ of $20 \%$ Triton X-100 in $0.1 \mathrm{M}$ phosphate buffer, $\mathrm{pH} 7.4,7.5 \mathrm{ml}$ of $2 \%$ agarose in a $0.1 \mathrm{M}$ phosphate

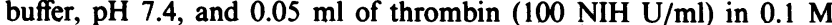
phosphate buffer, $\mathrm{pH} 7.4$ (the latter two solutions were kept at $54^{\circ} \mathrm{C}$ ).

\section{Results}

Elevation of plasma fibrinolytic system parameters after oral administration of varying doses of UK in normal human subjects. This study was designed to establish a minimum oral UK dose which would develop a plasma fibrinolytic state in the human subject. Three single consecutive oral doses, 15,000 IU, 30,000 IU, and 60,000 IU, of clinical-type HMW-UK were administered to each subject at 1-wk intervals. The three fibrinolytic parameters that showed significant elevation were UK-specific amidolytic activity, plasmin (protease) activity and ELT. UK-specific amidolytic activity was elevated between 2 and $6 \mathrm{~h}$ (Fig. 1). However, plasmin (protease) activity increased after $6 \mathrm{~h}$, and was elevated between 8 and $12 \mathrm{~h}$ (Fig. 2), showing continuous activation of plasminogen to plasmin by the continuous presence of a plasminogen activator for at least $12 \mathrm{~h}$. The ELT was shortened between 4 and $12 \mathrm{~h}$ (Fig. 3), also indicating prolonged fibrinolytic activity (both plasminogen activator and plasmin activities). Each subject was his/her internal control, receiving the increasing doses, consecutively, at weekly intervals. A single intravenous dose of 30,000 IU given as a bolus was used in another group of subjects for comparative purposes. During the first hour after administration, the intravenous dose also showed significant elevation of UK-specific amidolytic activity, and plasmin (protease) generation (Figs. 1 and 2), and also a shortening of the ELT (Fig. 3).

In both the oral and intravenous groups, some elevation in the FDP was found with the 30,000 IU and 60,000 IU doses but they were not significant. Also, very little change occurred in both the plasminogen and antiplasmin levels at both the three oral doses used and the intravenous dose. The activated partial thromboplastin times, the recalcification times, and thrombin times, using standard methods (2), were all within normal ranges.

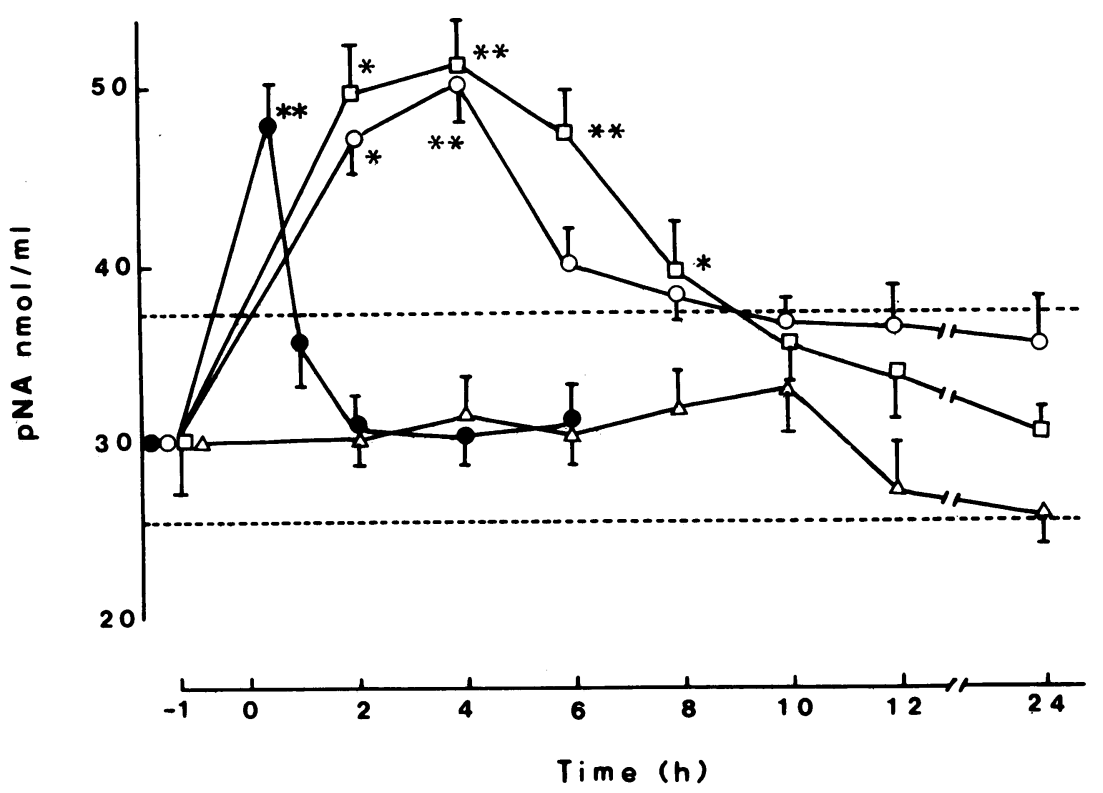

Figure 1. Plasma amidolytic activity as pNA liberated per milliliter of plasma. $-\Delta-, 15,000 \mathrm{IU}$ oral administration group; - $-, 30,000 \mathrm{IU}$ oral administration group; $-\square-, 60,000 \mathrm{IU}$ oral administration group; - $--, 30,000$ IU intravenous administration group. ${ }^{*} P \leq 0.05 ;{ }^{* *} P$ $\leq 0.01$. Significant difference from the physiological range (=---二). Mean \pm SE, $32 \pm 5.5$. 


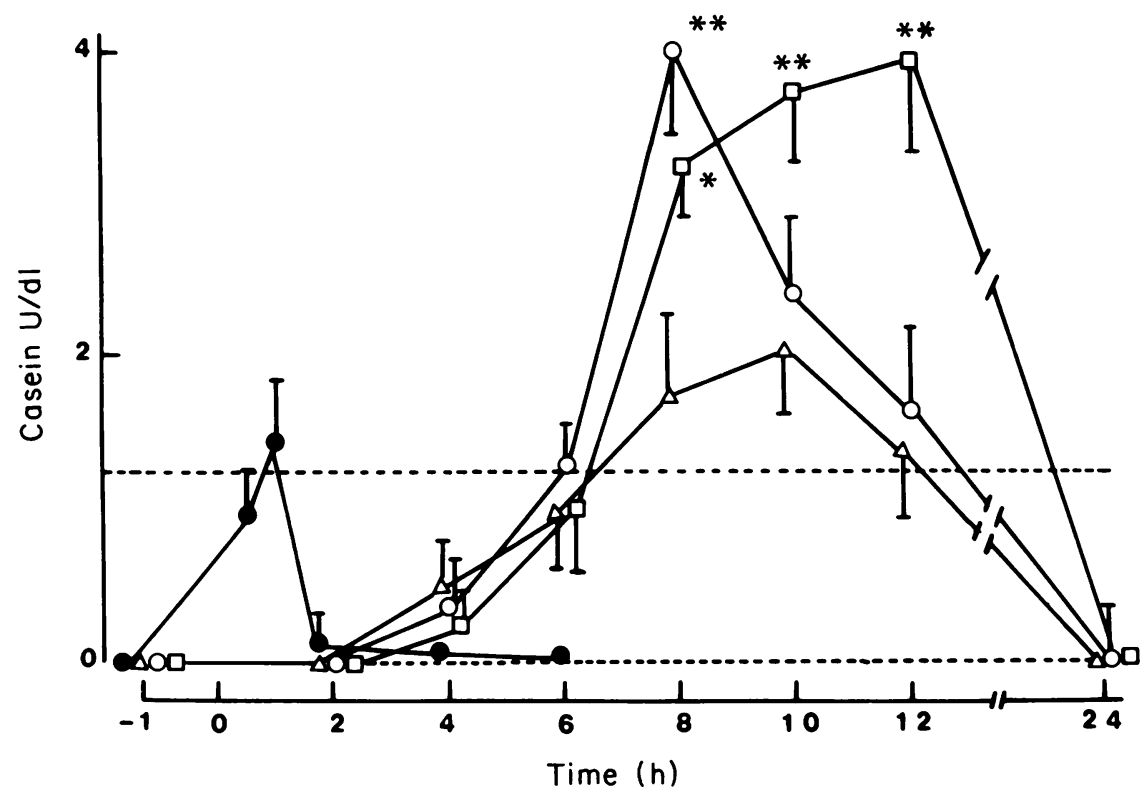

Figure 2. Plasma plasmin activity in casein $\mathrm{U} /$ dl plasma. $-\Delta-, 15,000$ IU oral administration group; $-0-, 30,000$ IU oral administration group; $-\square-, 60,000$ IU oral administration group; - $\bullet-, 30,000$ IU intravenous administration group. ${ }^{*} P \leq 0.05 ;{ }^{* *} P$ $\leq 0.01$. Significant difference from the physiological range $(=--=-)$. Mean $\pm \mathrm{SE}, 0.6 \pm 0.6$.
Pure HMW-UK, in a single dose of 120,000 IU (in four capsules), was given orally to each of 10 subjects for $1 \mathrm{~d}$ and each of 10 subjects daily for $7 \mathrm{~d}$, and another group of 10 subjects were each given four placebo capsules, in a single dose, daily for $7 \mathrm{~d}$. The plasma fibrinolytic parameters were measured on plasma pools of each group. After oral administration of HMW-UK for $1 \mathrm{~d}$ and daily for $7 \mathrm{~d}$, the individual subjects in the two groups showed similar plasma fibrinolytic states, namely, an increase in plasma UK-specific amidolytic and plasmin activities, and a shortening of the ELT as shown in Figs. 1, 2, and 3, with clinical-type HMW-UK. The 7-d placebo group showed the same data as found in the physiological range. These data show that a plasma fibrinolytic state was induced in human subjects given pure HMW-UK orally, as shown with the clinical-type HMW-UK given orally. The data do not show a clear-cut dose response; in the following experiments, only the 120,000 IU dose was used.

Isolation of plasminogen activators from the plasma of patients given $H M W-U K$ orally. Experiments were carried out on the isolation of plasma plasminogen activators from blood samples drawn from individuals in the placebo (7-d), 1-d, and $7-d$ groups. The assays used can reflect both UK and tissue plasminogen activator activities.

A sequential two-step affinity chromatography method was developed for isolating UK-type proteins from plasma samples. The first step utilizes an ACH-Sepharose column, which permits us to isolate plasma serine proteases, including tissue plasminogen activator and UK-type proteins, perhaps both active and inactive; DFP-inactivated UK is also adsorbed to this affinity column. The second step utilizes a specific rabbit anti-HMWUK-IgG-Sepharose column, which permits us to isolate the specific UK-type proteins.

Step 1: affinity chromatography with ACH-Sepharose. 20 $\mathrm{ml}$ of each plasma sample (pool) containing $400 \mathrm{KIU}$ of Trasylol and $25 \mathrm{mM}$ benzamidine $\cdot \mathrm{HCl}$ was passed through an $\mathrm{ACH}$-Sepharose column (wet volume of gel occupies 2.0 $\times 5.0 \mathrm{~cm}$ ) equilibrated with $100 \mathrm{mM}$ phosphate buffer, $\mathrm{pH}$ 7.4. After washing with $20-30$ vol of $100 \mathrm{mM}$ phosphate buffer, $\mathrm{pH} 7.4$, containing $2,000 \mathrm{mM} \mathrm{NaCl}$ until the absorbance at $280 \mathrm{~nm}$ was zero, the column was eluted with $50 \mathrm{ml}$ of the

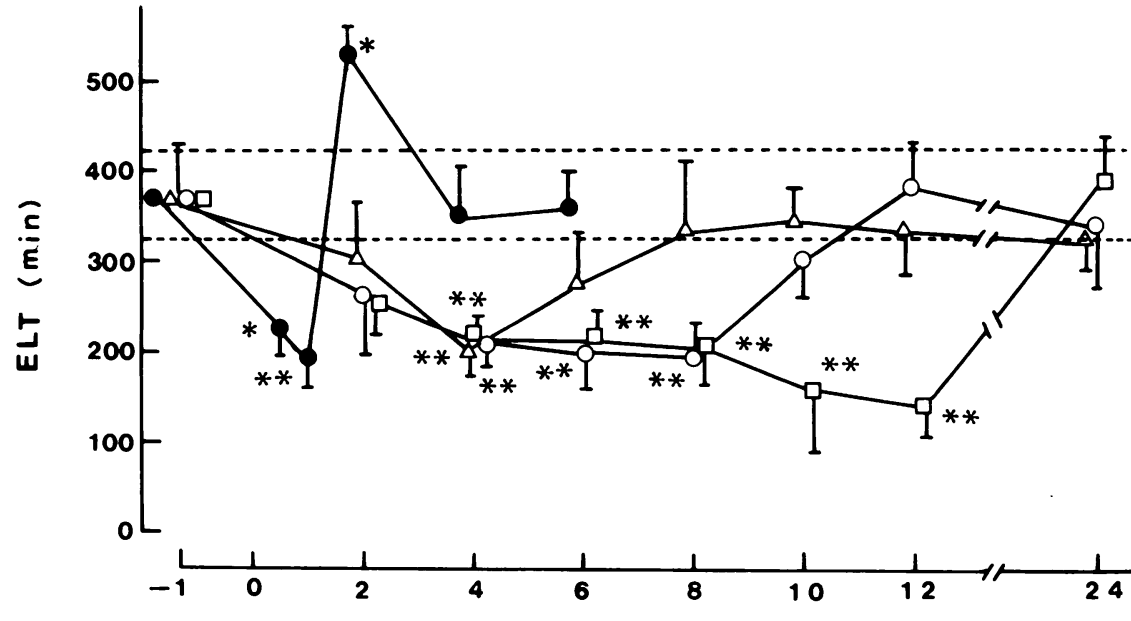

Time $(h)$
Figure 3. Plasma ELT. $-\Delta-, 15,000 \mathrm{IU}$ oral administration group; - $-, 30,000$ IU oral administration group; $\square \square-, 60,000 \mathrm{IU}$ oral administration group; $-\bullet-, 30,000 \mathrm{IU}$ intravenous administration group. ${ }^{*} P \leq 0.05$; ${ }^{* *} \ddagger P \leq 0.01$. Significant difference from the physiological range (=-z--). Mean \pm SE, $375 \pm 50$. 
Table I. Comparison of Urokinase-Specific Amidolytic and Glu-plasminogen Activator Activities in Plasma, and Isolated Fractions after Oral Administration of Highly Purified High Molecular Weight Urinary Urokinase in Normal Human Subjects

\begin{tabular}{|c|c|c|c|c|c|c|c|c|}
\hline \multirow[b]{2}{*}{$\begin{array}{l}\text { Method of } \\
\text { urokinase } \\
\text { administration }\end{array}$} & \multicolumn{2}{|l|}{ Plasma* } & \multicolumn{3}{|c|}{ Affinity adsorbed-eluted fraction (Step 1) } & \multicolumn{3}{|c|}{$\begin{array}{l}\text { Immunoadsorbent adsorbed-eluted fraction } \\
\text { (IAEF) (Step 2) }\end{array}$} \\
\hline & $\begin{array}{l}\text { Amidolytic } \\
\text { activity }\end{array}$ & $\begin{array}{l}\text { Glu-plg } \\
\text { activator } \\
\text { activity }\end{array}$ & Protein & $\begin{array}{l}\text { Amidolytic } \\
\text { activity }\end{array}$ & $\begin{array}{l}\text { Glu-plg } \\
\text { activator } \\
\text { activity }\end{array}$ & Protein & $\begin{array}{l}\text { Amidolytic } \\
\text { activity }\end{array}$ & $\begin{array}{l}\text { Glu-plg } \\
\text { activator } \\
\text { activity }\end{array}$ \\
\hline & $I U / d l \ddagger$ & $I U / d l \ddagger$ & $m g / d l \neq$ & $I U / d l \ddagger$ & $I U / d l \ddagger$ & $m g / d l \ddagger$ & $I U / d l \neq$ & $I U / d l \neq$ \\
\hline Placebo (7-d) & 467 & 0 & 4.90 & 455 & 0 & 0.317 & 0 & 0 \\
\hline $1-d$ & 1,780 & 0 & 5.15 & 1430 & 21 & 0.413 & 205 & 210 \\
\hline $7-d$ & 2,011 & 0 & 6.80 & 1645 & 33 & 0.792 & 420 & 425 \\
\hline
\end{tabular}

* Data are average of five 20 -ml purification experiments. $¥$ Original plasma.

same buffer containing $8 \mathrm{M}$ urea. The adsorbed and eluted fraction was dialyzed against the phosphate-buffered saline (PBS) at $4^{\circ} \mathrm{C}$ overnight, and then $25 \mathrm{mM}$ benzamidine $\cdot \mathrm{HCl}$ was added before the next step (affinity adsorbed-eluted fraction). As shown in Table I, serine protease and UK-type proteins could be isolated from the orally administered HMWUK plasma samples (5.15 and $6.80 \mathrm{mg}$ protein/dl plasma in the 1-d and 7-d groups, respectively), and 7-d placebo plasma sample $(4.90 \mathrm{mg}$ protein/dl plasma). The affinity adsorbedeluted fractions, prepared from the 1-d and 7-d orally administered HMW-UK plasma samples, showed some Glu-plasminogen activator activity, 21-33 IU/dl original plasma, respectively, probably both UK and tissue plasminogen activator. No Glu-plasminogen activator activity was found in the 7-d placebo plasma fraction. All of the amidolytic activity found in the 7-d placebo plasma sample was adsorbed to the $\mathrm{ACH}$ Sepharose column, and $\sim 80 \%$ of the amidolytic activity of the orally administered HMW-UK plasma samples were adsorbed to the column, showing the high specificity of the column for plasma serine proteases. There was no Glu-plasminogen activator activity found in the original plasma samples due to the complexing of transported urokinase with either a transport protein or an inhibitor.

Step 2: immunoadsorbent chromatography with specific rabbit anti-HMW-UK-IgG-Sepharose. The affinity adsorbedeluted fractions, from each of the three $20-\mathrm{ml}$ plasma samples, were each passed through a specific rabbit anti-HMW-UKIgG-Sepharose 4B column $(2.0 \times 5.0 \mathrm{~cm})$ equilibrated with $0.1 \mathrm{M}$ Tris-phosphate buffer at $\mathrm{pH}$ 8.0. The column was washed with $100 \mathrm{ml}$ of the same buffer containing $2 \mathrm{M} \mathrm{NaCl}$, $0.1 \mathrm{M}$ benzamidine $\cdot \mathrm{HCl}$, and $1 \%$ Triton $\mathrm{X}-100$, and then 100 $\mathrm{ml}$ of the same buffer containing no Triton $\mathrm{X}-100$. Elution of the UK-type proteins was achieved with $50 \mathrm{ml}$ of the same buffer containing $2 \mathrm{M} \mathrm{NaCl}$ and $8 \mathrm{M}$ urea, without benzamidine $\cdot \mathrm{HCl}$, and 4-ml fractions were collected. UK-specific amidolytic activity was found in both the unadsorbed fraction, and, the adsorbed-eluted fraction from the orally administered HMW-UK plasma samples. The adsorbed-eluted fraction from the anti-HMW-UK-IgG-Sepharose 4B column was pooled, dialyzed against PBS containing $25 \mathrm{mM}$ benzamidine $\cdot \mathrm{HCl}$ at $4^{\circ} \mathrm{C}$ overnight. Then, the solution was subjected to a second immunoadsorbent chromatography cycle identical with the first. By these methods, UK-type proteins were isolated only in the adsorbed-eluted fraction, from the 1-d and 7-d, and 7d placebo plasma affinity adsorbed-eluted fractions (step 2 fractions).
The amidolytic and Glu-Plg activator activities found in the original plasma samples, affinity adsorbed-eluted fractions and immunoadsorbent adsorbed-eluted fractions (IAEF) following oral administration of HMW-UK, are summarized in Table I. First, we would like to compare the IAEF data in the $1-\mathrm{d}$ and 7-d groups with those in the 7-d placebo group. We have isolated $0.413 \mathrm{mg}$ protein/dl original plasma, with a specific activator activity of $508 \mathrm{IU} / \mathrm{mg}$ protein, from the human subjects receiving HMW-UK orally for $1 \mathrm{~d}$ (1-d group), $0.792 \mathrm{mg} / \mathrm{dl}$ from the 7-d group, with a specific activator activity of $537 \mathrm{IU} / \mathrm{mg}$ protein, and $0.317 \mathrm{mg} / \mathrm{dl}$, from the $7-\mathrm{d}$ placebo group, with no activity. The UK-specific amidolytic activity in the 1-d group was $205 \mathrm{IU} / \mathrm{dl}$, in the $7-\mathrm{d}$ group the activity was $420 \mathrm{IU} / \mathrm{dl}$, whereas no activity was found in the 7-d placebo group. Therefore, the increase in amidolytic activity after oral administration of HMW-UK in the 1-d and 7-d groups was due in part to UK-type activity. None of the unadsorbed fractions, which had high amidolytic activity, had Glu-Plg activator activity. The Glu-Plg activator activity found in the 1-d and 7-d affinity adsorbed-eluted fraction was low, $21 \mathrm{IU} / \mathrm{dl}$ and $33 \mathrm{IU} / \mathrm{dl}$ original plasma, respectively, but increased at least 10-fold in the 1-d and 7-d IAEF. The UKamidolytic activities and Glu-Plg activator activities were the same, indicating that the measurement of activator activity by two different methods was identical. There was twofold more UK-type protein in the 7-d IAEF than the 1-d IAEF. Assuming a total plasma volume of $2,400 \mathrm{ml} / 60 \mathrm{~kg}$ individual, we have isolated an equivalent of 10,200 IU of UK-type activity (plasminogen activator activity) in the 7-d IAEF which is equivalent to $\sim 8 \%$ of the administered dose (120,000 IU); the specific Glu-Plg activator activity of the 7-d IAEF was $536 \mathrm{IU} /$ mg protein.

Enzymatic properties of the isolated UK-proteins in the $I A E F$. The kinetic parameters of Glu-Plg activation of the 1d IAEF, which contained $8 \%$ active sites (four preparations had $8 \pm 1 \%$ active sites), were determined and compared with that of the highly purified parent urinary HMW-UK $(6,9)$. As shown in Table II, the apparent Michaelis constant of activation, $\mathrm{K}_{\mathrm{plg}}$, for this fraction was $2.00 \mu \mathrm{M}$, which was similar to the $\mathrm{K}_{\text {plg }}$ of the parent HMW-UK, namely $1.18 \mu \mathrm{M}$. On the other hand, the catalytic rate constant of activation, $k_{\mathrm{plg}}$, of the fraction was $11.46 \mathrm{~min}^{-1}$, which was $\sim 2.5$-fold lower than the $\mathrm{k}_{\mathrm{plg}}$ of the parent HMW-UK, namely, $28.65 \mathrm{~min}^{-1}$. The second order rate constant of activation, $\mathrm{k}_{\mathrm{plg}} / \mathrm{K}_{\mathrm{plg}}$, of the IAEF was fourfold less than the $\mathrm{k}_{\mathrm{plg}} / \mathrm{K}_{\mathrm{plg}}$ value of the parent HMW-UK, which was calculated to be $24.3 \mu \mathrm{M}^{-1} \mathrm{~min}^{-1}$. Although the 
Table II. Kinetics of Activation Parameters of Human GluPlasminogen by Parent Urinary HMW-UK Compared with the Plasma Immunoadsorbent Adsorbed-Eluted Fraction (IAEF) Isolated from the 1-d Group

\begin{tabular}{llll}
\hline Enzyme & $\mathrm{K}_{\mathrm{pk}}$ & $\mathrm{k}_{\mathrm{pk}}$ & $\mathrm{k}_{\mathrm{pw}} / \mathrm{K}_{\mathrm{pk}}$ \\
\hline & $\mu M$ & $\mathrm{~min}^{-1}$ & $\mu M^{-1} \mathrm{~min}^{-1}$ \\
$\begin{array}{r}\text { Parent HMW-UK } \\
\begin{array}{r}\text { Immunoadsorbent } \\
\text { adsorbed-eluted } \\
\text { fraction (IAEF) }\end{array}\end{array}$ & 1.18 & 28.65 & 24.28 \\
\hline
\end{tabular}

slopes of the Lineweaver-Burk plots were different, the isolated plasma urokinase-type enzyme is similar to the parent urinary HMW-UK in the activation of Glu-Plg. We had previously reported $\mathrm{K}_{\mathrm{plg}}$ and $\mathrm{k}_{\mathrm{plg}}$ values of $1.90 \mu \mathrm{M}$ and $50.41 \mathrm{~min}^{-1}$, respectively, for a different highly purified urinary HMW-UK preparation, and $\mathrm{K}_{\mathrm{plg}}$ and $\mathrm{k}_{\mathrm{plg}}$ values of $1.67 \mu \mathrm{M}$ and 22.72 $\min ^{-1}$, respectively, for a highly purified LMW-UK $(6,9)$. The kinetic parameters of Glu-Plg activation of all of the UK activator species studied, both urinary and plasma, are all very similar; therefore, all of the UK-type enzymes are similar to one another as plasminogen activators.

$S D S-P A G E$ and zymogram of UK-type protein in IAEF. As shown in Table I, the differences in protein concentrations and specific activities of UK-type protein in the IAEF in the three groups made us speculate that there may be differences in the biochemical properties of the UK-type proteins isolated from each of the three groups. Each UK-type protein from the three IAEFs was applied to SDS-PAGE, and the plasminogen activator activities of the protein bands separated on the gel were determined by the zymographic technique. As shown in Fig. $4 A$, the IAEF from the 7-d placebo group $(12.4 \mu \mathrm{g}$ protein/lane) as well as from the 1-d group (16.4 $\mu$ g protein/ lane) showed two bands in positions of molecular weights of $\sim 140,000$ and $\sim 120,000$, higher than the molecular weights of HMW-UK. In addition to these two bands, the IAEF from the 7-d group ( $31.5 \mu \mathrm{g}$ protein/lane) showed a major band, $\sim 50 \%$ of the total protein, of molecular weight $\sim 53,000$ in the same molecular weight position as the band of the highly purified HMW-UK standard. The difference in protein concentration in the IAEF between 7-d placebo, or 1-d group, and the 7-d group was assumed to be due to the presence of this protein band corresponded to a molecular weight of $\sim 53,000$. This 53,000 protein is probably a minor, trace, protein in either the 1-d or 7-d placebo groups. The protein concentration of the samples used in lanes $a, b$, and $c$ were related to the yields obtained in the IAEF (Table I).

On the other hand, as shown in Fig. $4 \mathrm{~B}$, zymograms of the IAEF showed some interesting and important results. The two high molecular weight protein bands $(\sim 140,000$ and 120,000 ) in the three IAEF did not have any plasminogen activator activity on the zymogram. Although the IAEF from the 7-d placebo and 1-d groups did not show visible protein bands at the $53,000 \mathrm{~mol}$ wt position of HMW-UK on SDSPAGE, the lysis bands indicated plasminogen activator activity at the position of HMW-UK on the zymogram. The plasminogen activator activities in the lysis bands on the zymogram were determined from a UK standard curve between IU and lysis area $\left(\mathrm{mm}^{2}\right)$ on the zymogram, and it was confirmed that all of the enzyme activity (IU) in the IAEF from the 1-d and 7-d groups could be recovered in the protein bands which coincided with the lysis band on the zymogram. Although the IAEF from the 7-d placebo group did not show any UK-

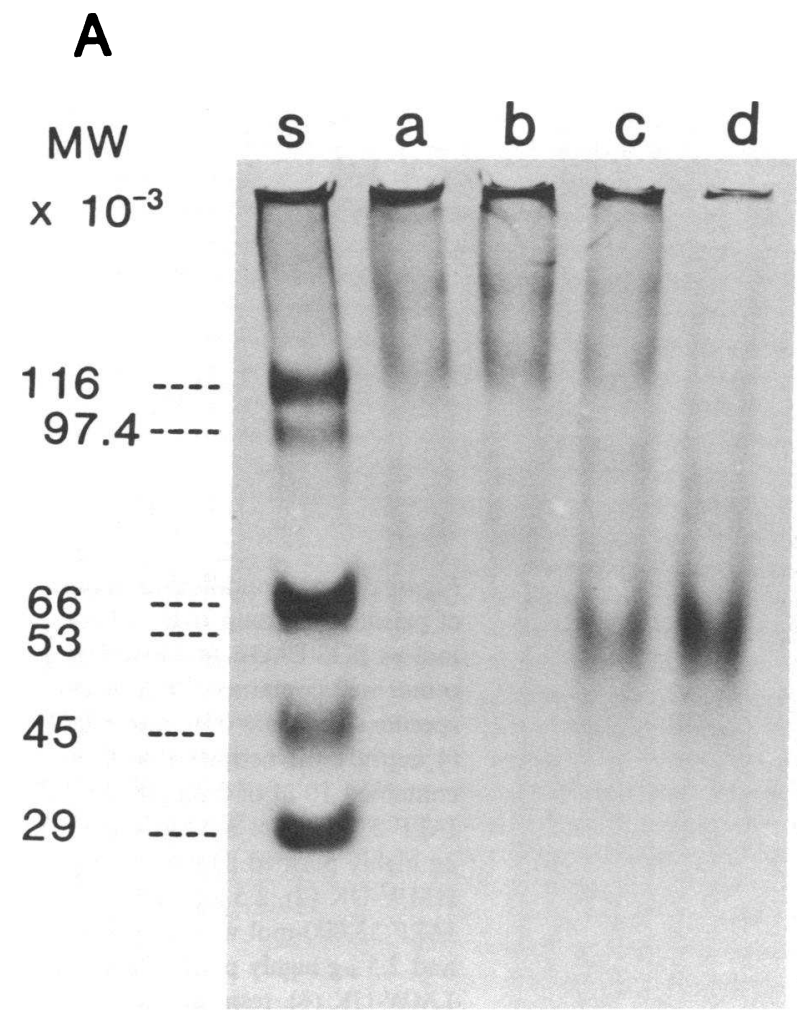

8

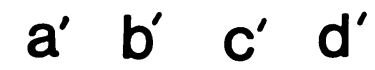

Figure 4. SDS-PAGE analysis and zymogram of IAEF. SDS-PAGE and zymogram were carried out as described under Methods. $(A)$ SDS-PAGE of IAEF and HMWUK standard. Lane $a$, IAEF from 7-d placebo group (12.4 $\mu \mathrm{g})$; lane $b$, from the 1-d group $(16.4 \mu \mathrm{g})$; lane $c$, from the 7-d group (31.5 $\mu \mathrm{g})$; lane $d$, HMW-UK standard $(35.2 \mu \mathrm{g})$; lane $s$, mol wt standard kit (Sigma; $\beta$-galactosidase, 116,000 ; phosphorylase B, 97,400 ; bovine albumin, 66,000; egg albumin, 45,000; carbonic anhydrase, $29,000)(30 \mu \mathrm{g})$. (B) Zymogram of IAEF and HMW-UK standard. The SDS-PAGE gel was extracted with $2.5 \%$ Triton X-100 for 30 $\mathrm{min}$, and overlaid onto a plasminogen-rich fibrin-agar plate. Lane $a^{\prime}$, IAEF from placebo group (12.4 $\mu \mathrm{g})$; lane $b^{\prime}$, from 1-d group (1.64 $\mu \mathrm{g})$; lane $c^{\prime}$, from 7-d group (1.58 $\mu \mathrm{g})$; lane $d^{\prime}$, HMW-UK standard $(0.008 \mu \mathrm{g})$. Lysis areas $\left(\mathrm{mm}^{2}\right)$ of $a^{\prime}, b^{\prime}$, and $c^{\prime}$ were almost the same as that obtained with $0.9 \mathrm{IU}$ of HMW-UK standard. 
specific amidolytic and Glu-plg activator activities, the zymogram showed the presence of UK-like plasminogen activator activity in this IAEF, $20 \mathrm{IU} / \mathrm{dl}$ original plasma, similar to that reported by Tissot et al. (19). The reason for the difference in the Glu-plasminogen activator activity in the 7-d placebo, 20 $\mathrm{IU} / \mathrm{dl}$, and the 1-d and 7-d IAEF, 210 IU/dl to $\sim 425 \mathrm{IU} /$ $\mathrm{dl}$, when using active site measurements (amidolytic activity) (1-40 IU) and plasminogen activation in an isolated highly purified system (plasminogen activator activity) (0-4 IU), and zymograph method (0-1 IU) is probably due to the sensitivities of the assays. The 7-d placebo group IAEF could contain a small amount of UK-zymogen, which is activated by plasmin generated during zymography; all of the trace UK-zymogen found in the other fractions from the 1-d and 7-d groups could have been converted to the enzyme during the isolation procedures, probably due to some plasmin contamination in the early fractions (steps 1 and 2). What are the two high molecular weight protein bands found in SDS-PAGE? The antigenic determinants of these two protein bands are similar to those found in the urinary HMW-UK protein because they are bound to the specific rabbit anti-HMW-UK-IgG-Sepharose column. They are either higher molecular weight forms of UK (20), or undissociated UK-UK inhibitor complexes. This problem is now under investigation in our laboratory.

Purification of UK-type protein in 7-d IAEF by SDS-PAGE. We further purified the UK-type protein of $53,000 \mathrm{~mol} \mathrm{wt}$ from the 7-d group IAEF by SDS-PAGE. Aliquots of $30 \mu \mathrm{g}$ of IAEF were applied to 12 gel slots. After electrophoresis, the gels were sliced at the position of $53,000 \mathrm{~mol} w \mathrm{wt}$, and the slices were extracted with $5 \mathrm{ml}$ of $0.1 \mathrm{M}$ phosphate buffer $\mathrm{pH} 7.4$ containing $0.2 \%$ Triton $\mathrm{X}-100$ overnight at $4^{\circ} \mathrm{C}$. The supernatant, after glass-wool filtration, was dialyzed against $0.1 \mathrm{M}$ phosphate buffer at pH 7.4 overnight at $4^{\circ} \mathrm{C}$ and concentrated against Carbowax 20,000. By this preparative SDS-PAGE procedure, $0.29 \mathrm{mg}$ of protein with $360 \mathrm{IU}$ of Glu-Plg activator activity was recovered from $0.79 \mathrm{mg}$ of the fraction containing
425 IU of Glu-Plg activator activity, with a specific activity of $1,241 \mathrm{IU} / \mathrm{mg}$ protein, and a recovery of $85 \%$. Since the specific activity of the pure HMW-UK standard is $110,000 \mathrm{IU} / \mathrm{mg}$ protein, the active $53,000 \mathrm{~mol}$ wt UK-type protein, after preparative SDS-PAGE, is $\sim 1 \%$ of the total protein, indicating that $\sim 99 \%$ of the $53,000 \mathrm{~mol}$ wt UK-type protein may be in an inactive form, or the protein is a UK-zymogen with a low specific activity. All of the purified $53,000 \mathrm{~mol} w \mathrm{wK}$-type protein, after preparative SDS-PAGE could be bound to specific rabbit anti-HMW-UK-IgG-Sepharose.

The 7-d IAEF SDS-PAGE fraction, containing the 53,000 mol wt protein, formed a precipitin band with the specific rabbit IgG antibody to HMW-UK in double immunodiffusion (Fig. 5). These results show that the purified 53,000 mol wt UK-type protein has common antigenic determinants with urinary HMW-UK, and also with LMW-UK.

Peptide chain analysis of the plasma 53,000 mol wt UKtype protein. The purified 53,000 mol wt UK-type protein was reduced in $0.1 \mathrm{M}$ phosphate buffer, $\mathrm{pH} 7.4$, containing $1 \% 2$ mercaptoethanol, at $37^{\circ} \mathrm{C}$ for $30 \mathrm{~min}$. As shown in Fig. $6 \mathrm{~A}$, after reduction, the $53,000 \mathrm{~mol}$ wt protein band as well as the highly purified HMW-UK standard separated into two chains that have the same mol wts of 33,000 and 20,000 , respectively. The UK-type heavy chains of $33,000 \mathrm{~mol}$ wt did not have any plasminogen activator activity on the zymogram after reduction (Fig. $6 \mathrm{~B}$ ).

Isolation and characterization of plasminogen from the plasma of patients given pure HMW-UK orally. Plasminogen was isolated from the patients' plasma samples, from the 7-d placebo, 1-d, and 7-d groups, after removal of the UK-type proteins by ACH-Sepharose affinity chromatography. The remaining unadsorbed plasma was subjected to a continuous three-step sequential affinity chromatography method using Zn-chelated-Sepharose (21) (step 1) to remove serine proteases and possible tissue-type plasminogen activators, followed by ACH-Sepharose (step 2) to remove any residual UK-type

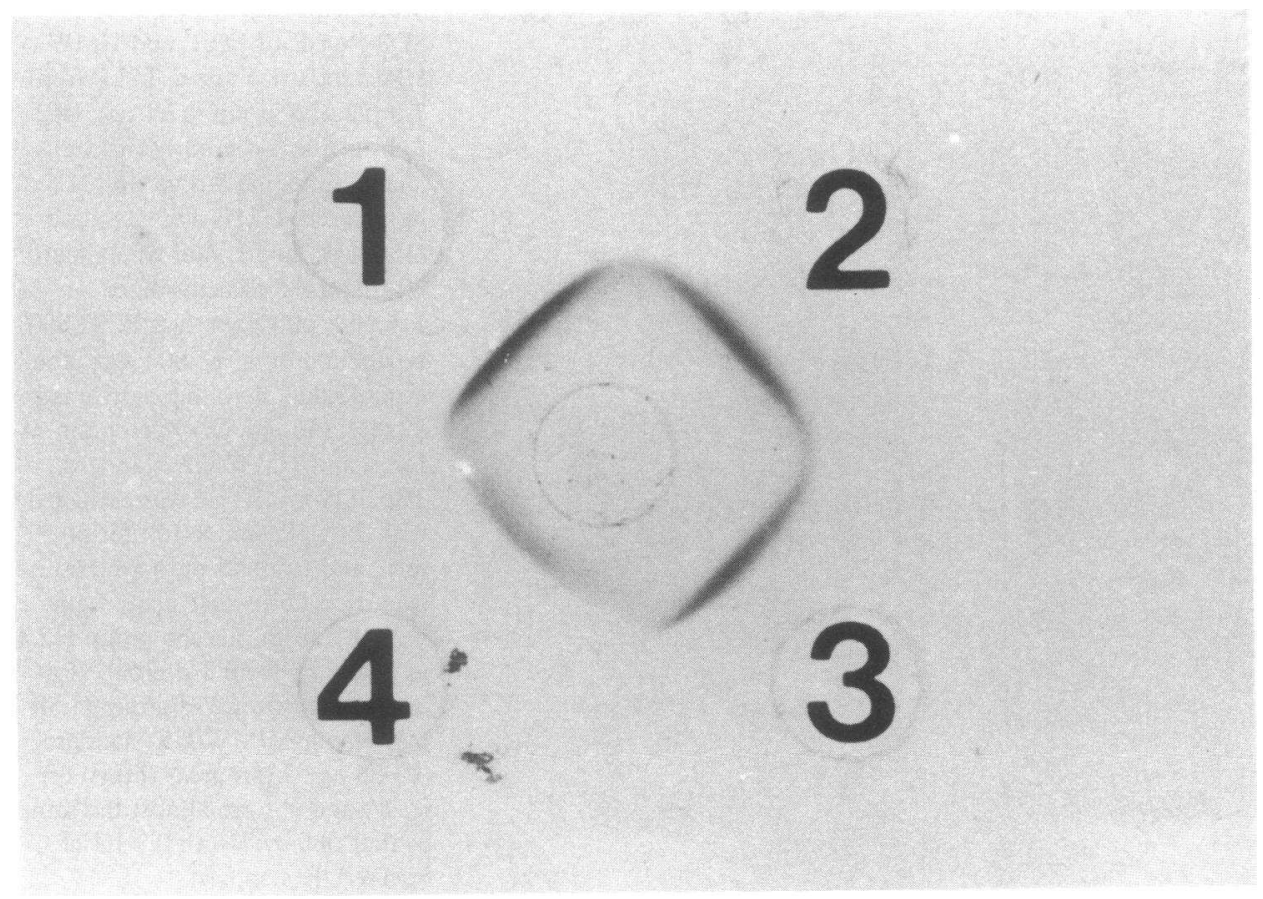

Figure 5. Immunodiffusion pattern of plasma 7-d group IAEF 53,000mol wt SDS-PAGE fraction. The center well contained $10 \mu \mathrm{l}$ monospecific anti-HMW-UK rabbit IgG $(4 \mathrm{mg} / \mathrm{ml})$; the peripheral wells each contained $10 \mu \mathrm{l}$ of $5 \mu \mathrm{g}$ plasma 7 -d IAEF 53,000-mol wt fraction (1), 5 $\mu \mathrm{g}$ highly purified parent urinary HMW-UK (2), $2.5 \mu$ g plasma 7-d IAEF 53,000-mol wt fraction (3), and $2.5 \mu \mathrm{g}$ highly purified urinary LMW-UK (4), respectively. 


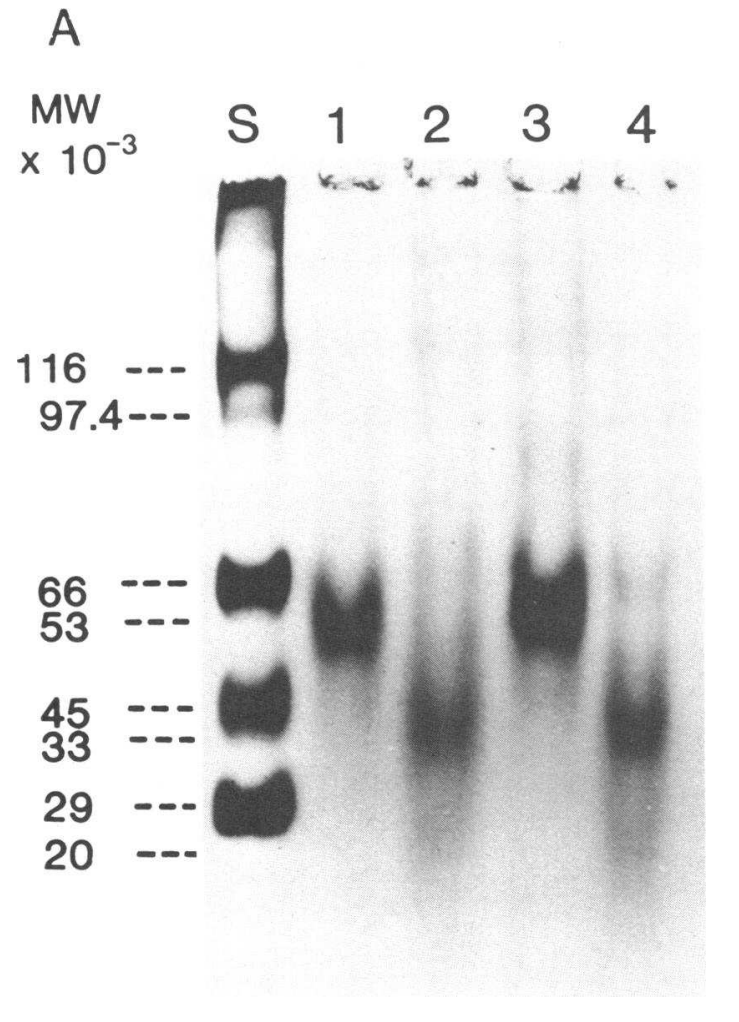

proteins, and L-lysine-substituted-Sepharose (22) (step 3) to remove plasminogen. Approximately 60 to $70 \mathrm{ml}$ of the unadsorbed plasma (pool) from $\mathrm{ACH}$-Sepharose was passed through the three affinity columns at room temperature, and washed with $0.1 \mathrm{M}$ phosphate buffer, $\mathrm{pH}$ 7.4. Each column contained $10-\mathrm{ml}$ volumes of each affinity reagent. The Llysine-substituted-Sepharose column was washed with the phosphate buffer until the absorbance at $280 \mathrm{~nm}$ was zero. It was then eluted with $0.2 \mathrm{M} \epsilon-\mathrm{ACA} / 0.1 \mathrm{M}$ phosphate buffer, pH 7.4. Fractions, $2.5 \mathrm{ml}$, were collected with the protein being eluted between 12 and $20 \mathrm{ml}$. The protein fraction was precipitated at $35 \%$ ammonium sulfate, at $4{ }^{\circ} \mathrm{C}$ overnight. The precipitate was removed by centrifugation at $12,000 \mathrm{rpm}$ and dissolved in $0.01 \mathrm{M}$ phosphate/0.02 $\mathrm{M}$ lysine/0.15 $\mathrm{M} \mathrm{NaCl}$ buffer, pH 7.4, containing $100 \mathrm{KIU}$ Trasylol/ml, to a concentration of $\sim 10 \mathrm{mg} / \mathrm{ml}$ protein. The solutions were clarified by centrifugation at $12,000 \mathrm{rpm}$. The functional protein yield was 7-d placebo group, $4.9 \mathrm{mg} \%$; 1-d group, $7.4 \mathrm{mg} \%$; and 7-d group, $6.5 \mathrm{mg} \%$. Each plasminogen fraction, as is, and reduced, was analyzed by SDS-PAGE; the results of these experiments are shown in Fig. 7. The 7-d placebo group plasminogen fraction (lane 1) shows mainly the Glu-form(s), 93\% Glu-form and 7\% Lys-form(s), whereas in the 1-d group and 7-d group fractions there was a mixture of the Glu-form(s) and Lysform(s). The 1-d group fraction (lane 2) showed $76 \%$ Gluform(s), $21 \%$ Lys-form(s), and 3\% of a plasmin-plasmin inhibitor complex; the 7-d group fraction (lane 3) showed $27 \%$ Glu-form(s), $67 \%$ Lys-form(s), and $6 \%$ of a plasmin-plasmin inhibitor complex. In order to determine if there was any free plasmin in the preparations, the fractions were completely reduced and alkylated and analyzed by SDS-PAGE (Fig. 7).
Figure 6. Peptide chain analysis of 53,000-mol wt plasma urokinase-type protein. $(A)$ SDS-PAGE of 53,000-mol wt urokinase-type protein and HMW-UK standard before and after reduction. Reduction was carried out by incubating the sample in $0.1 \mathrm{M}$ phosphate buffer, $\mathrm{pH} 7.4$, containing $1 \% 2$-mercaptoethanol at $37^{\circ} \mathrm{C}$ for $30 \mathrm{~min}$. Lane 1, 53,000-mol wt urokinase-type protein $(30 \mu \mathrm{g})$; lane 2 , reduced $53,000-\mathrm{mol}$ wt urokinase-type protein (30 $\mu \mathrm{g})$; lane 3 , HMW-UK standard (35 $\mu \mathrm{g})$; lane 4, reduced HMW-UK standard (35 $\mu \mathrm{g})$; lane $S$, mol wt standard kit $(30 \mu \mathrm{g})$. (B) Zymogram of 53,000-mol wt urokinasetype protein and HMW-UK standard before and after reduction. Lane 1', 53,000-mol wt urokinase-type protein $(1.53 \mu \mathrm{g})$; lane $2^{\prime}$, reduced 53,000 -mol wt UK-type protein $(1.53 \mu \mathrm{g})$; lane $3^{\prime}$, HMW-UK standard $(0.008$ $\mu \mathrm{g})$; lane 4 ', reduced HMWUK standard $(0.008 \mu \mathrm{g})$.
No plasmin heavy $(A)$ and light $(B)$ chains were found in the 7-d placebo group fraction. In the 1-d group fraction, a trace of plasmin was found but in the 7-d group fraction, 9\% plasmin was found, calculated from the heavy chain fraction. Therefore, the Lys-form(s) of plasminogen found in the 7-d group fraction was primarily the zymogen(s), with some contaminating plasmin.

\section{Discussion}

In these studies, we have shown that the oral administration of urinary HMW-UK in a group of normal human subjects induced a plasma fibrinolytic state (Figs. 1-3), suggesting transport of the HMW-UK across the intestinal tract, and stimulation of synthesis and/or release of UK-type proteins. Transport, and stimulation and/or release of UK-type proteins and tissue plasminogen activator, were confirmed in an animal model (5) using radiolabeled UK. A 53,000 mol wt UK-type protein was isolated from the plasma of patients given 120,000 IU pure HMW-UK orally, in a single dose, daily for $7 \mathrm{~d}$, by a sequential two-step affinity chromatography method. The final product, 7-d immunoadsorbent adsorbed-eluted fraction (IAEF), was a UK-type protein with low specific plasminogen activator activity, $536 \mathrm{IU} / \mathrm{mg}$ protein. The $1-\mathrm{d}$ IAEF, with $8 \%$ active sites, which had a similar specific activity, had considerably less 53,000 mol wt protein. However, the enzyme in a kinetic analysis had similar kinetic parameters to pure urinary HMW-UK, indicating similar activator enzymes. When a minimal daily dose of 120,000 IU pure HMW-UK was used either for $1 \mathrm{~d}$ or for $7 \mathrm{~d}$, the yield of the 7-d IAEF was twofold higher in protein and activator activity than the 1-d IAEF. 


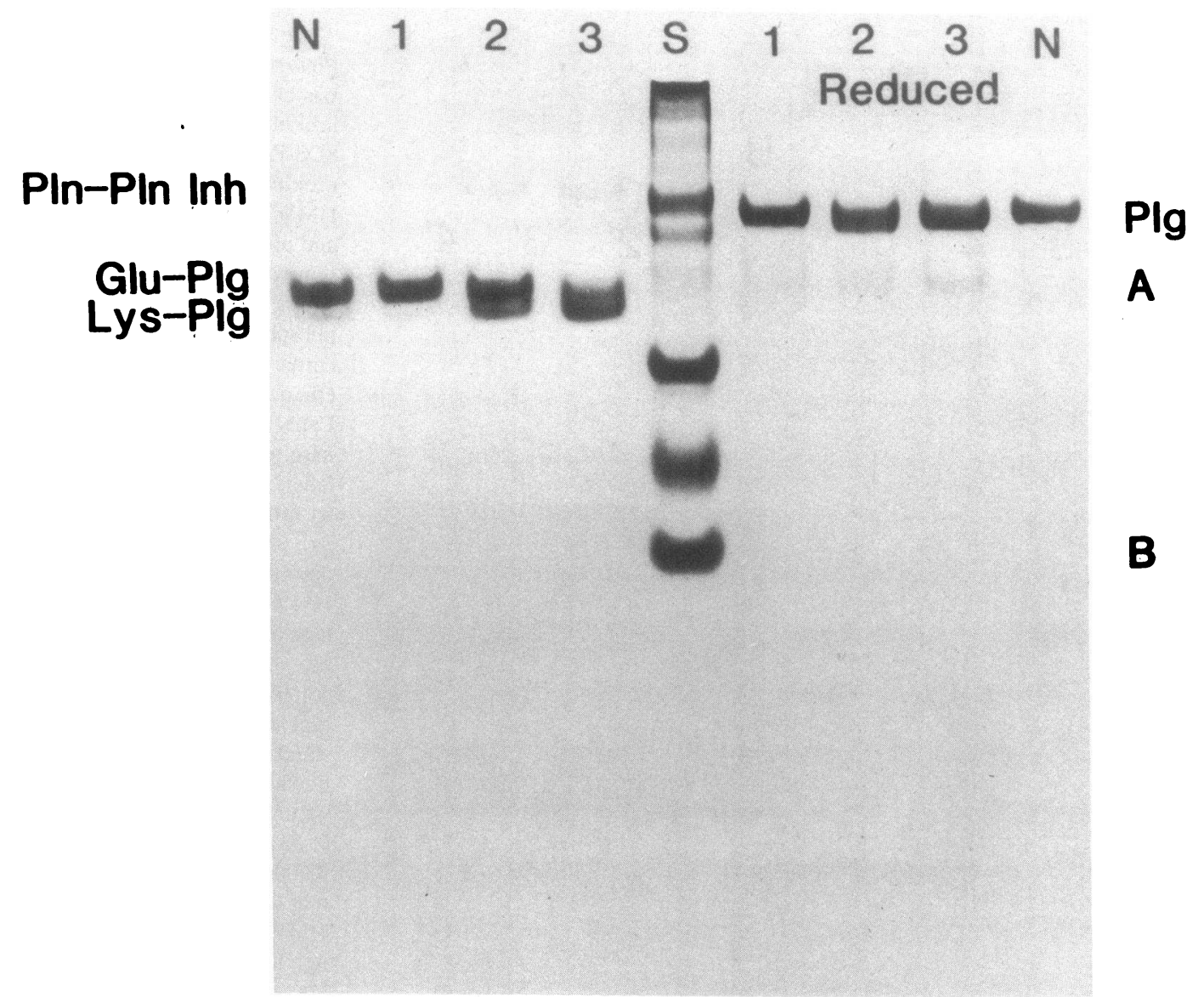

Figure 7. SDS-PAGE analysis of plasminogen isolated from the plasma of patients given HMW-UK and placebo orally. Reduction and alkylation were performed as follows. $50 \mu \mathrm{l}$ of plasminogen sample solution $(2-3 \mathrm{mg} / \mathrm{ml})$ was incubated in $40 \mathrm{ml}$ of $8 \mathrm{M}$ urea and $2.5 \mu \mathrm{l}$ of $1 \% 2$-mercaptoethanol in boiling water for $10 \mathrm{~min}, 20$ $\mu \mathrm{l}$ of iodoacetate in $\mathrm{NaOH}(29.8 \mathrm{mg}$ iodoacetate $/ 40 \mu \mathrm{l}$ of $4 \mathrm{M}$ $\mathrm{NaOH}$ ) was added, and the solution was incubated at room temperature for $10 \mathrm{~min}$. Lanes 1 and 1 ': 7-d placebo group plasminogen

Although this is not a dose-response curve, the possibility exists that longer dosage periods, or increased dosage, could produce higher levels of the UK-type protein.

It has been established that the $53,000 \mathrm{~mol}$ wt urinary HMW-UK protein has a two-chain structure linked by a single disulfide bond (23) and the chains can be separated by SDSPAGE after reduction. In the present study, we first succeeded in isolating a $53,000 \mathrm{~mol} w \mathrm{w}$ UK-type protein from the 7-d IAEF by SDS-PAGE. The purified material had the same antigenicity and two-chain structure as active urinary HMWUK. These results suggests that this UK-type protein may be HMW-UK. However, its specific activity was $1,241 \mathrm{IU} / \mathrm{mg}$ protein, $\sim 1 \%$ of the specific activity of pure urinary HMWUK $(110,000 \mathrm{IU} / \mathrm{mg}$ protein). Although the intact two-chain form of the $53,000 \mathrm{~mol}$ wt urinary $\mathrm{HMW}-\mathrm{UK}$ protein is catalytically active, is inhibited by DFP, and will incorporate $\left[{ }^{3} \mathrm{H}\right] \mathrm{DFP}$ into its active site in the $33,000 \mathrm{~mol}$ wt chain (23), almost all of the $53,000 \mathrm{~mol}$ wt plasma UK-type protein was catalytically inactive, and this UK-type protein incorporated only $0.003 \mathrm{~mol}$ of $\left[{ }^{3} \mathrm{H}\right.$ ]DFP per mole of protein, even though it has a two-chain structure. Both Wun et al. (24) and Nielsen et al. (25) isolated an inactive single-chain UK-zymogen from the culture medium of the human epidermoid carcinoma and human glioblastoma cells in tissue culture, respectively, that sample, $24 \mu \mathrm{g}$ unreduced, and $12 \mu \mathrm{g}$ reduced-alkylated; lanes 2 and 2': 1-d group plasminogen sample, $29 \mu \mathrm{g}$ unreduced, and $14 \mu \mathrm{g}$ reduced-alkylated; lanes 3 and 3': 7-d group plasminogen sample, 32 $\mu \mathrm{g}$ unreduced, and $16 \mu \mathrm{g}$ reduced-alkylated; lane $N$ : Glu-plasminogen standard (Kabi, $30 \mu \mathrm{g}$ ); lane $S$ : mol wt standard kit (Sigma, $30 \mu \mathrm{g}$ ). Pln-PIn Inh, plasmin- $\alpha_{2}$-plasmin inhibitor complex; Plg, plasminogen; $A$ and $B$ chains, plasmin-derived heavy $(A)$ and light $(B)$ chains of plasmin, respectively.

can be converted to an active two-chain enzyme by plasmin. Wun et al. (26) also suggested that the major fractions of the urokinase zymogen isolated by immunoadsorbent affinity column chromatography from enriched plasma fractions may exist in a conformation that is predisposed to degradation rather than to activation by plasmin treatment. Neither the UK-specific amidolytic nor Glu-plg activator activities of the $53,000 \mathrm{~mol} \mathrm{wt}$ UK-type protein isolated in this study could be enhanced by plasmin treatment.

In these studies on the isolation of UK-type proteins from the plasma of human subjects given urinary HMW-UK orally, we have found that when using the sequential two-step affinity chromatography method followed by the preparative SDSPAGE method, large amounts of the $53,000 \mathrm{~mol}$ wt UK-type protein $(0.29 \mathrm{mg} / \mathrm{dl}$ plasma) can be isolated from the plasma of the 7-d group, compared to the small amounts isolated from the plasma of the $1-\mathrm{d}$ group $(<0.03 \mathrm{mg} / \mathrm{dl}$ plasma). This indicates that each of the human subjects in the 7-d group contain a total amount of $\sim 7.0 \mathrm{mg}$ of UK-type protein in whole blood, assuming a plasma volume of $2,400 \mathrm{ml} / 60 \mathrm{~kg}$ individual. Each individual in the 7-d group was given a total amount of $7.63 \mathrm{mg}$ of pure HMW-UK $(840,000 \mathrm{IU}$ of UK with a specific activity of $110,000 \mathrm{IU} / \mathrm{mg}$ protein). Therefore, it is speculated that if all of the plasma UK-type protein 


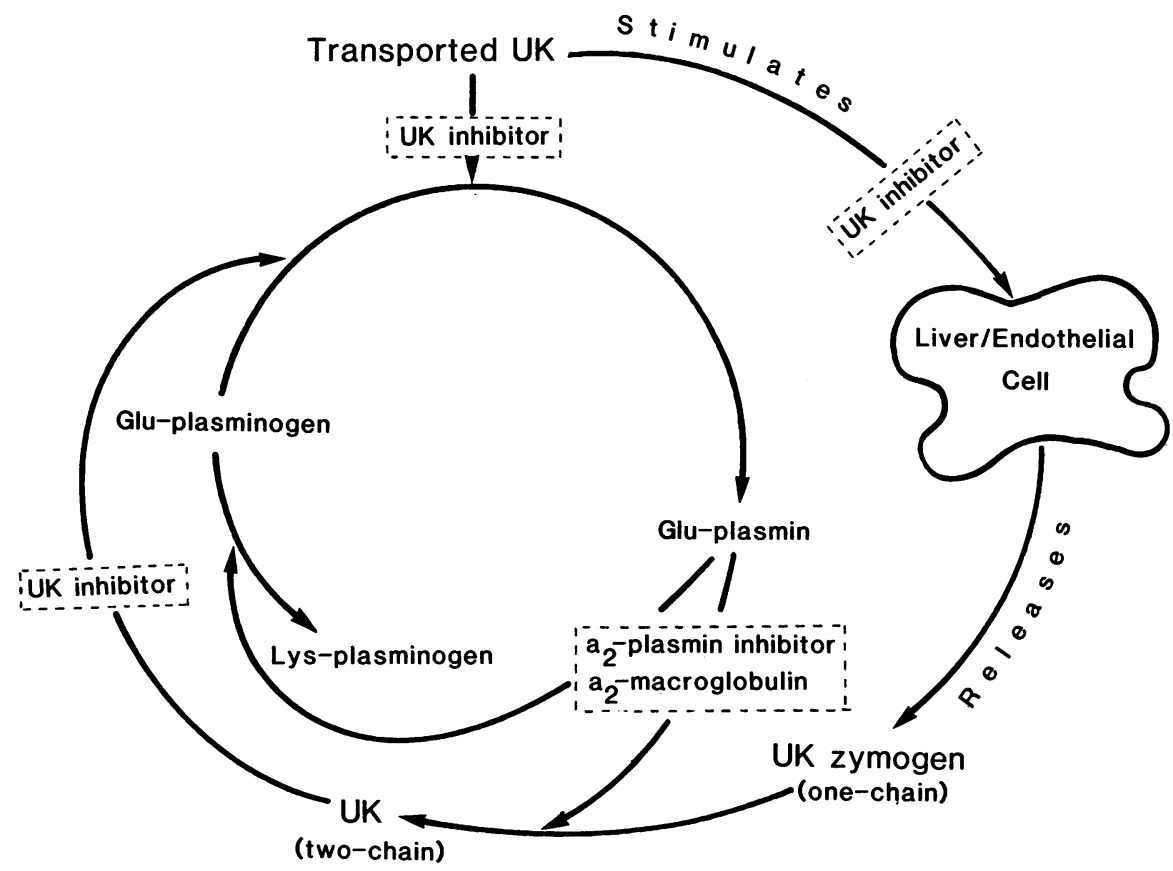

Figure 8. Activation mechanism of the plasma fibrinolytic enzyme system after oral administration of human urinary HMW-UK. originated in the orally administered HMW-UK, $>92 \%$ of the HMW-UK was transported and appeared in the blood. This speculation is obviously illogical, because it is well known that the absorption rate of macromolecules across the intestinal tract of human subjects is at most $<10 \%$ of the total protein administered (27). We reported that in a dog model (5), a single duodenally-administered ${ }^{125} \mathrm{I} \mathrm{HMW}-\mathrm{UK}$ dose was transported and appeared in the plasma in $<45 \mathrm{~min}$. Also, the biological half-life of UK was found to be $<20 \mathrm{~min}$ (28).

We believe that orally administered HMW-UK stimulates the UK biosynthetic pathway, in perhaps the liver (29) and/or vascular endothelium (30), releasing a single chain UK-type protein, a zymogen form. The UK-zymogen is converted to a two-chain active UK form by plasmin, and any other factors, generated in plasma (see Fig. 2). After inducing the plasma fibrinolytic state, active UK is bound to a specific UK inhibitor(s), and eliminated from the blood as the enzyme-enzyme inhibitor complex. This process is probably the reason why the oral administration of HMW-UK can maintain a plasma fibrinolytic state for much longer intervals after administration than the intravenous administration of HMW-UK. We also would like to propose the possibility that the cumulative effect of the oral administration of HMW-UK may be expected even during fibrinolytic therapy, because the Glu-plg activator activity in the IAEF of the 7-d group was two times higher than that of the 1-d group, and a large amount of the 53,000 mol wt plasma UK-type protein could be isolated only from the 7-d group.

The 53,000 mol wt protein was isolated from plasma containing the protein, in probably UK-UK inhibitor complexes. A rapid specific inhibitor to both tissue plasminogen activator and UK, which forms possible stoichiometric complexes, has been recently reported $(31,32)$. During the fractionation of plasma samples containing these inactive UK-UK inhibitor complexes, they are first adsorbed to $\mathrm{ACH}$-Sepharose and eluted with buffers containing $8 \mathrm{M}$ urea, followed by adsorption to specific rabbit anti-HMW-UK-IgG-Sepharose and eluted with $8 \mathrm{M}$ urea. The proteins were then subjected to SDS-PAGE electrophoresis. The $53,000 \mathrm{~mol} \mathrm{wt}$ two-chain
UK-type protein was found to be essentially inactive. The dissociation of the UK-UK inhibitor complex resulted in an inactive enzyme. The trace amounts of active UK, $\sim 1 \%$, could be the result of dissociation of a different UK-UK inhibitor complex, perhaps with $\alpha_{2}$-plasmin inhibitor (32), a slow UK inhibitor, where the enzyme is still in the active form.

The oral administration of UK in human subjects produced a fibrinolytic state with resulting free plasmin (and free plasminplasmin inhibitor complexes) causing the continuous conversion of Glu-plasminogen to Lys-plasminogen (7-d group, 67\% Lysform). It was recently reported that a modified form of plasminogen was found in plasma activated by UK (33). The continual presence of Lys-plasminogen in the circulation could be an important component in fibrin-thrombus resolution, since Lys-plasminogen binds better to the fibrin-thrombus and is more easily, and readily, activatable by plasminogen activators (34-36). We now can propose a general mechanism for the effect of the oral administration of urokinase in human subjects on stimulating the biosynthesis/release of UK-type proteins, and their effect on the conversion of Glu-plasminogen to Lysplasminogen (Fig. 8). The new plasma components, e.g., the 53,000 mol wt, UK-zymogen, and Lys-plasminogen, could play an important role in clot resolution of the fibrin-thrombus in thromboembolic diseases. The infusion of a single-chain 55,000 mol wt UK zymogen, isolated from a transformed kidney cell culture medium, into animal models, was found to induce clot lysis (37). Work is in progress on the isolation of the UK zymogen in patients with pancreatitis given oral HMW-UK and treated with Trasylol to prevent conversion of the zymogen to the enzyme by plasmin.

The oral administration of 120,000 IU HMW-UK daily for $7 \mathrm{~d}$ was found to be clinically effective in patients with cerebral thrombosis in a multicenter double blind study $(K$. Sasaki, Zeria Pharmaceutical Co., personal communication). This clinical study compared favorably to that reported by Abe et al. (38) using 60,000 IU HMW-UK intravenously, daily for $7 \mathrm{~d}$, in patients with cerebral thrombosis, also in a multicenter double blind study. 


\section{Acknowledgments}

We are grateful to Pai-Hua Lum for excellent technical assistance and to Dorothy Bell for her diligent typing of the manuscript.

This work was supported in part by grant HL34276 from the National Institutes of Health.

\section{References}

1. Sherry, S. 1977. Therapeutic fibrinolysis: past, present and future. In Thrombosis and Urokinase. R. Paoletti and S. Sherry, editors. Academic Press, London. 1-9.

2. Sumi, H., K. Sasaki, N. Toki, and K. C. Robbins. 1980. Oral Administration of urokinase. Thromb. Res. 20:711-714.

3. Toki, N., H. Sumi, K. Sasaki, and K. C. Robbins. 1981. Oral administration of high molecular weight urokinase in human subjects and in an experimental dog model. In Progress in Fibrinolysis. J. F. Davidson, I. M. Nilsson, and B. Astedt, editors. Vol. V. Churchill Livingstone, Edinburgh. 439-440.

4. Robbins, K. C., H. Sumi, K. Sasaki, and N. Toki. 1982. The transport of high molecular weight urinary urokinase across the intestinal tract of dogs and human subjects. In Urokinase: Basic and Clinical Aspects. P. M. Mannucci and A. D'Angelo, editors. Serono Symposium No. 48. Academic Press, London. 63-71.

5. Sasaki, K., S. Moriyami, H. Sumi, K. Toki, and K. C. Robbins. 1985. The transport of ${ }^{125}$ I-labeled human high molecular weight urokinase across the intestinal tract in a dog model with stimulation of synthesis and/or release of plasminogen activators. Blood. In press.

6. Wohl, R. C., L. Summaria, and K. C. Robbins. 1979. Physiological activation of the human fibrinolytic system. Isolation and characterization of human plasminogen variants, Chicago I and Chicago II. J. Biol. Chem. 254:9063-9069.

7. Sumi, H., K. Sasaki, and M. Muramatu. 1978. A simple and rapid purification method of urokinase using a $\left[N^{\alpha}-(\epsilon\right.$-aminocaproyl)DL-homoarginine hexylester]-Sepharose column. Acta Haematol. Jpn. 41:766-770.

8. Chase, T., Jr., and E. Shaw. 1969. Comparison of the esterase activities of trypsin, plasmin and thrombin on guanidinobenzoate esters. Titration of the enzymes. Biochemistry. 8:2212-2224.

9. Wohl, R. C., L. Summaria, and K. C. Robbins. 1980. Kinetics of activation of human plasminogen by different activator species. J. Biol. Chem. 255:2005-2013.

10. Claeson, G., P. Friberger, M. Knös, and E. Eriksson. 1978. Method for determination of prekallikrein in plasma, grandular kallikrein and urokinase. Haemostasis. 7:76-78.

11. Milstone, H. 1941. A factor in normal human blood which participates in streptococcal fibrinolysis. J. Immunol. 42:109-116.

12. Garvey, M. B., and J. M. Black. 1972. The detection of fibrinogen/-fibrin degradation products by means of a new antibodycoated latex particle. J. Clin. Pathol. (Lond.). 25:680-682.

13. Ishihara, H., N. Toki, and T. Yamura. 1974. Measurement of plasminogen and two antiplasmins by $L$-lysine Sepharose affinity chromatography. Hiroshima J. Med. Sci. 23:237-246.

14. Wun, T.-C., W.-D. Schleuning, and E. Reich. 1982. Isolation and characterization of urokinase from human plasma. J. Biol. Chem. 257:3276-3283

15. Day, E. D., A. P. Ball, D. Jeffords, W. T. Woodard, Jr., and D. Silver. 1969. The immunoassay of human urokinase. Thromb. Diath. Haemorrh. 21:273-286.

16. Cuatrecasas, P. 1970. Protein purification by affinity chromatography. Derivatization of agarose and polyacrylamide beads. J. Biol. Chem. 245:3059-3065.

17. Ouchterlony, O. 1958. Diffusion in gel methods for immunological analysis. Prog. Allergy. 5:1-78.

18. Summaria, L., L. Arzadon, P. Bernabe, and K. C. Robbins. 1975. The activation of plasminogen to plasmin by urokinase in the presence of the plasmin inhibitor Trasylol. The preparation of plasmin with the same $\mathrm{NH}_{2}$-terminal heavy(A) chain sequence as the parent zymogen. J. Biol. Chem. 250:3988-3995.
19. Tissot, J. D., P. Schneider, J. Hauert, M. Ruegg, E. K. O. Kruithof, and F. Bachmann. 1982. Isolation from human plasma of a plasminogen activator identical to urinary high molecular weight urokinase. J. Clin. Invest. 70:1320-1323.

20. Harvey, S., J. Minowada, H. Takita, L. Kover, and G. Markus. 1982. Urokinase-like plasminogen activators of unusually high molecular weight secreted by a cell line derived from a human lung cancer case. J. Biol. Chem. 257:5645-5651.

21. Porath, J., and O. Birgit. 1983. Immobilized metal ion affinity adsorption and immobilized metal ion affinity chromatography of biomaterials. Serum protein affinities for gel-immobilized iron and nickel ions. Biochemistry. 22:1621-1630.

22. Robbins, K. C., and L. Summaria. 1976. Plasminogen and Plasmin. Methods Enzymol. 45:257-273.

23. Sumi, H., and K. C. Robbins. 1983. A functionally active heavy chain derived from human high molecular weight urokinase. J. Biol. Chem. 258:8014-8019.

24. Wun, T.-C., L. Ossowski, and E. Reich. 1982. A proenzyme form of human urokinase. J. Biol. Chem. 257:7262-7268.

25. Nielsen, L. S., J. G. Hansen, L. Skriver, E. L. Wilson, K. Kaltoft, J. Zenthen, and K. Dánø. 1982. Purification of zymogen to plasminogen activator from human glioblastoma cells by affinity chromatography with monoclonal antibody. Biochemistry. 21:64106415 .

26. Wun, T.-C., W.-D. Schleuning, and E. Reich. 1982. Isolation and characterization of urokinase from human plasma. J. Biol. Chem 257:3276-3283.

27. Walker, W. A., and K. J. Isselbacher. 1974. Uptake and transport of macromolecules by the intestine. Possible role in clinical disorders. Gastroenterology. 67:531-550.

28. Alkjaersig, N., and A. Fletcher. 1977. Metabolism of urokinase. In Thrombosis and Urokinase. R. Paoletti and S. Sherry, editors. Academic Press, London. 129-141.

29. Barlow, G. H., S. L. Firestone, and K. C. Robbins. 1982. Identification of the plasminogen activator(s) produced by the transformed liver cell line, SK-HEP-1. Thromb. Res. 32:29-34.

30. Booyse, F. M., G. Osikowicz, S. Feder, and J. Scheinbuks. 1984. Preliminary characterization of the $M_{r}=55,000$ urokinase-like plasminogen activator isolated from human umbilical vein endothelial cells. J. Biol. Chem. 259:7198-7205.

31. Juhan-Vague, I., B. Moerman, F. DeCock, M. F. Ailland, and D. Collen. 1984. Plasma levels of a specific inhibitor of tissue-type plasminogen activator (and urokinase) in normal and pathological conditions. Thromb. Res. 33:523-530.

32. Kruithof, E. K. O., C. Tran-Thang, A. Ransijn, and F. Bachmann. 1984. Demonstration of a fast-acting inhibitor of plasminogen activators in human plasma. Blood. 64:907-913.

33. Yamamoto, J., U. Okamoto, S. Kojima, S. Morita, and K. Fujii. 1983. Production of the modified form of human plasminogen in the plasma activated by urokinase. Jpn. J. Physiol. 33:469-484.

34. Claeys, H., and J. Vermylen. 1974. Physico-chemical and proenzyme properties of $\mathrm{NH}_{2}$-terminal glutamic acid and $\mathrm{NH}_{2}$-terminal lysine human plasminogen. Biochim. Biophys. Acta. 342:351-359.

35. Thorsen, S. 1975. Differences in binding to fibrin of native plasminogen and plasminogen modified by proteolytic degradation. Biochim. Biophys. Acta. 393:55-65.

36. Sakata, Y., J. Mimuro, and N. Aoki. 1984. Differential binding of plasminogen to crosslinked and noncrosslinked fibrins: its significance in hemostatis defect in Factor XIII deficiency. Blood. 63:1393-1401.

37. Gurewich, V., R. Pannell, S. Lovie, P. Kelley, R. L. Suddith, and R. Greenlee. 1984. Effective and fibrin-specific clot lysis by a zymogen precursor form of urokinase (pro-urokinase). A study in vitro and in two animal species. $J$. Clin. Invest. 73:1731-1739.

38. Abe, T., M. Kazama, I. Naito, H. Kanaya, R. Machino, A Igata, Y. Tazaki, M. Kameyama, F. Goto, H. Maezawa, H. Watanabe, K. Urushiyama, H. Togi, N. Sakuragawa, J. Atarashi, S. Kito, G. Araki, H. Onodera, E. Otomo, and N. Ogawa. 1981. Clinical effect of urokinase $(60,000$ units/day) on cerebral infarction: comparative study by means of multiple center double blind test. Blood \& Vessel. 12: 342-358. 